\title{
PENYELESAIAN PERSELISIHAN PERDATA MASYARAKAT DESA MENURUT UNDANG-UNDANG NOMOR 6 TAHUN 2014 TENTANG DESA
}

\author{
Disca Yuli Ika Prabawati; Fakultas Hukum Universitas Islam Balitar; \\ Jl. Majapahit No.2-4, Kota Blitar, Jawa Timur; E-mail: discayuliika14@gmail.com
}

\begin{abstract}
This study is based on the fact that a village head's demands must be able to resolve problems and disputes in his area because actually conflicts or disputes are normal and inevitable as long as there is interaction between humans. This research tries to answer about the authority and role of the Village Chief in resolving civil society disputes according to Law Number 6 Year 2014 concerning Villages and what are the obstacles faced by the Village Head in resolving Village Community disputes and how the solutions are offered. The method used is a normative juridical method in this case is research conducted by examining the substance of legislation on the subject matter. The results of this study indicate that based on Article 26 (4) letter K of Act Number 6 of 2014 concerning Villages, the village head is obliged to resolve community disputes in the village. There are obstacles that hinder the process of resolving disputes properly, one of which is poor quality human resources. The solution offered is to improve the quality of human resources.
\end{abstract}

Keywords: Disputes, Civil Code, Village Law.

\section{PENDAHULUAN}

\section{Latar Belakang}

Indonesia merupakan negara yang memiliki daerah pedesaan yang banyak sehingga pembangunan pedesaan adalah untuk menempatkan desa sebagai sarana pembangunan usaha untuk mengurangi berbagai kesenjangan pendapatan. Kesenjangan kaya dan miskin, serta kesenjangan kota dan desa. ${ }^{1}$ Pengaturan Desa, telah ditetapkan beberapa pengaturan tentang Desa, yaitu Undang-Undang Nomor 22 Tahun 1948 tentang Pokok Pemerintahan Daerah, Undang-Undang Nomor 1 Tahun 1957 tentang Pokok-Pokok Pemerintahan Daerah, Undang-Undang Nomor 18 Tahun 1965 tentang Pokok-Pokok Pemerintahan Daerah, Undang-Undang Nomor 19 Tahun 1965 tentang Desa Praja Sebagai Bentuk Peralihan Untuk Mempercepat Terwujudnya Daerah Tingkat III di Seluruh Wilayah Republik Indonesia, Undang-Undang Nomor 5 Tahun 1974 tentang Pokok-Pokok Pemerintahan di Daerah, Undang-Undang Nomor 5 Tahun 1979 tentang Pemerintahan Desa, Undang-Undang Nomor 22 Tahun 1999 tentang Pemerintahan Daerah, dan terakhir dengan Undang-Undang Nomor 32 Tahun 2004 tentang Pemerintahan Daerah.

Dalam pelaksanaannya, pengaturan mengenai Desa tersebut belum dapat mewadahi segala kepentingan dan kebutuhan masyarakat Desa yang hingga saat ini sudah berjumlah sekitar 73.000 (tujuh puluh tiga ribu) Desa dan sekitar 8.000 (delapan ribu) kelurahan. Selain itu, pelaksanaan pengaturan Desa yang selama ini berlaku sudah tidak sesuai lagi dengan perkembangan zaman, terutama antara lain menyangkut kedudukan masyarakat hukum adat, demokratisasi, keberagaman, partisipasi masyarakat, serta

\footnotetext{
${ }^{1}$ Agung Septian Wijanarko, Peran Badan Usaha Milik Desa dalam Pemberdayaan Masyarakat, http://eprints.upnjatim.ac.id/1/file 1.pdf, tanggal 23 Desember 2015, diakses pada tanggal 24 Juli 2018
} 
kemajuan dan pemerataan pembangunan sehingga menimbulkan kesenjangan antarwilayah, kemiskinan, dan masalah sosial budaya yang dapat mengganggu keutuhan Negara Kesatuan Republik Indonesia ${ }^{2}$.

Hadirnya regulasi baru tentang pemerintah daerah melalui Undang-Undang Nomor 9 Tahun 2015 tentang Pemerintahan Daerah melahirkan kerangka kerja baru pemerintahan daerah yakni otonomi daerah. Hal ini memberikan nuansa baru atas partisipasi dan pemberdayaan masyarakat (empowerment) dalam penyelenggaraan pembangunan termasuk kegiatan pembangunan melalui koridor pemerintahan desa.

Kabupaten Blitar merupakan salah satu daerah di Propinsi Jawa Timur yang secara geografis Kabupaten Blitar terletak pada 111 25' - 112 20' BT dan 7 57-8 9'51 LS berada di Barat daya Ibu Kota Propinsi Jawa Timur - Surabaya dengan jarak kurang lebih 160 Km. Secara administrasi Pemerintah Kabupaten Blitar terbagi menjadi 22 kecamatan, 220 desa, 28 kelurahan, 759 dusun/Rukun Warga (RW) dan sebanyak 6.978 Rukun Tetangga (RT). Kecamatan yang memiliki jumlah penduduk terbesar adalah Kecamatan Ponggok yaitu sebanyak 104.083 jiwa, sedangkan kecamatan yang memiliki jumlah penduduk paling sedikit adalah Kecamatan Bakung dengan jumlah penduduk 30.475 jiwa. Namun begitu apabila jumlah penduduk dibandingkan luas wilayah masing - masing kecamatan, maka kecamatan Kanigoro memiliki kepadatan penduduk paling tinggi karena diduga berdekatan dengan wilayah Kota Blitar. Hal tersebut didukung data bahwa kecamatan kecamatan yang berbatasan dengan wilayah Kota Blitar seperti Kanigoro, Garum, Kademangan, dan Nglegok.Adapun kecamatan yang memiliki kepadatan penduduk paling rendah adalah Kecamatan Wates.Wonotirto merupakan salah satu kecamatan yang terletak di selatan dimana terdapat sebuah desa Ngeni disana.

Secara historis dan kultural, masyarakat Blitar, terutama di pedesaan telah terbiasa menggunakan pranata lokal berbasis kearifan lokal dalam menyelesaikan perselisihan.Ungkapan seperti menang tanpa ngasorake, ana rembug di rembug, rukun agawe santoso, siro yo ingsun-ingsun yo siro, atau ngalah dhuwur wekasane dan sebagainya, adalah nilai-nilai kearifan lokal dalam menyelesaikan perselisihan di masyarakat pedesaan Jawa pada umumnya. Demikian juga, ungkapan lokal yang mengedepankan harmoni, kedamaian, dan persaudaraan dalam penyelesaian perselsihan seperti segilikseguluk salunglung sabayantaka, paras paros sarpanaya, menyama braya di Bali. ${ }^{3}$

Sebagaimana diketahui bahwa pemerintahan desa merupakan struktur pemerintahan terbawah yang secara langsung berinteraksi dengan masyarakat dan segala potensi menuju masyarakat ideal bisa dikembangkan.Dengan demikian urusan pemerintahan yang menjadi kewenangan desa dan permasalahannya mencakup urusan pemerintahan dalam arti holistik. Dalam melaksanakan urusan kemasyarakatan, pemerintah desa dituntut lebih tanggap menyikapi dan menyelesaikan konflik yang terjadi ditengah-tengah warganya, pemerintah desa mampu bersifat netral, dengan mengedepankan prinsip kebenaran, tanpa harus memihak.

${ }^{2}$ Lihat dalam penjelasan Undang-Undang Nomor 6 Tahun 2014 tentang Desa.

3I Putu Gelgel. 2011. Peradilan Adat (Agama) Sebagai Resolusi Konflik.Bali Pos, Senin, 06 Oktober 2011. 
Suatu tantangan sekaligus tuntutan kepala desa mampu menyelesaikan persoalan dan sengketa di wilayahnya karena sesungguhnya konflik atau perselisihan adalah normal dan tidak dapat dielakkan sepanjang ada interaksi antar manusia. Dalam perspektif antropologi, perselisihan merupakan fenomena sosial yang tidak dapat dipisahkan dari kehidupan manusia, lebih-lebih lagi dalam masyarakat yang bercorak multi budaya.Ia adalah sesuatu yang tidak dapat dihindari dalam kehidupan bersama. ${ }^{4}$ Beberapa perselisihan di desa ngeni yang pernah muncul adalah persoalan waris, asusila yakni seorang laki-laki dewasa yang menginap di rumah warga ngeni dan bukan istrinya serta perkelahian siswa sekolah yang menegangkan. Persoalan tersebut dari sisi hukum dan secara teknis penyelesaian hukum ada dua pilihan bagi warga masyarakat dalam menyelesaikan perselisihan, yaitu melalui carajudicial (litigasi) oleh peradilan negara dan melalui cara non judicial (non litigasi) oleh pihak ketiga (mediator). ${ }^{5}$ Sejalan dengan ketentuan dalam Undang-Undang Nomor 6 Tahun 2014 tentang Desa yang menegaskan fungsi kepala desa sebagai penyelesai perselisihan. Pasal 26 (1) menyebutkan bahwa Kepala Desa bertugas menyelenggarakan Pemerintahan Desa, melaksanakan Pembangunan Desa, pembinaan kemasyarakatan Desa, dan pemberdayaan masyarakat Desa. Selanjutnya dalam melaksanakan tugas juga disebutkan khusus sebagai berikut :

"Kepala Desa berkewajiban menyelesaikan perselisihan masyarakat di Desa."6

Melihat pasal tersebut fungsi kepala desa sebagai penyelesai perselisihan sangat strategis dalam mendukung keamanan dan ketertiban di daerah. Sebenarnya kepala desa merupakan jabatan politis yang dalam pemilihannya dipilih langsung oleh masyarakat. Dengan kenyataan demikian memungkinkan kepala desa terpilih tidak mempunyai keahlian khusus dibidang pemerintahan. Apalagi kemampuan di bidang penyelesaian sengketa dan perselisihan desa atau yang terkait dengan aspek hukum baik dalam tataran konseptual kognitif maupun praktek. Lebih lagi pada akumulasi permasalahan yang muncul di desa dan potensi konflik yang ada merupakan tantangan dan ancaman tersendiri bagi kepala desa berikut perangkatnya.

\section{Rumusan Masalah}

1. Bagaimana kewenangan dan peran Kepala Desa dalam penyelesaian perselisihan perdata Masyarakat Desa menurut Undang-Undang Nomor 6 Tahun 2014 tentang Desa?

2. Apa saja kendala yang dihadapi oleh Kepala Desa dalam penyelesaian perselisihan Masyarakat Desa dan bagaimana solusinya?

\footnotetext{
4James, P. Spradley and David W. McCurdy, 1987, Conformity and Conflict,Reading in Cultural Antropogy, Little Brown and Company, 1987, h. 11.

${ }^{5}$ Sulistiyono, Adi. Mengembanngkan Paradigma Non-Litigasi di Indonesia. Sebelas Maret University Press: Surakarta, 2006, h. 130-131.

${ }^{6}$ Lihat Pasal 26 (4) huruf k pada Undang-Undang Nomor 6 Tahun 2014 tentang Desa.
} 


\section{METODE PENELITIAN}

Sesuai dengan tipe penelitian yuridis normatif maka yang diteliti adalah bahanbahan hukum sebagai library based, focusing on reading and analysis of the primary and secondary materials, 7 dengan mengumpulkan data sekunder. Pengumpulan data sekunder dimaksudkan sebagai upaya mendapatkan landasan teoritis yakni, dengan mempelajari peraturan-peraturan, dokumen-dokumen dan buku-buku yang ada kaitannya dengan masalah kewenangan dan peran Kepala Desa dalam penyelesaian perselisihan perdata Masyarakat Desa menurut Undang-Undang Nomor 6 Tahun 2014 tentang Desa ini, serta pendapat para sarjana (doktrin).

\section{PEMBAHASAN}

1. Kewenangan dan peran Kepala Desa Ngeni dalam penyelesaian perselisihan perdata masyarakat desa menurut Undang-Undang Nomor 6 Tahun 2014 tentang Desa.

Sesungguhnya konflik atau perselisihan adalah normal dan tidak dapat dielakkan sepanjang ada interaksi antar manusia. Dalam perspektif antropologi, perselisihan merupakan fenomena sosial yang tidak dapat dipisahkan dari kehidupan manusia, lebih-lebih lagi dalam masyarakat yang bercorak multi budaya.Ia adalah sesuatu yang tidak dapat dihindari dalam kehidupan bersama. Manifest konflik atau perselisihan mempunyai berbagai bentuk misalnya konflik antar pribadi, antar keluarga, antar kelompok dan lain sebagainya.

Pada prinsipnya kebijakan otonomi daerah memuat tentang pelaksanaan desentralisasi dimana dinamika kekuasaan harus menjunjung tinggi prinsip tata pemerintahan yang baik (good governance) seiring dengan paradigma sentralistik (upbottom) namun berganti antara kebijakan dari daerah ke pusat (bottom-up). Sehingga tata pemerintahan yang baik (good governance) bisa diartikan dengan suatu hubungan sinergis antara pemerintah pusat dengan daerah (desa) dengan batasan normatif. Kesemuanya ini merupakan kebutuhan masyarakat berupa kewenangan pelayanan kebutuhan pokok (basic service) dan pelayanan pengembangan sektor daerah. Perlu diingat, betapapun luasnya otonomi daerah, masyarakat berhak berpartisipasi dan mengawasi jalannya pengelolaan pemerintahan daerah atau desa. Dengan demikian semangat pelaksanaan otonomi daerah adalah keseimbangan peran antara pemerintah secara hierarki dengan institusi paling bawah yaitu pemerintah desa.

Undang-Undang Nomor 6 Tahun 2014 tentang Desa menggunakan istilah "perselisihan", untuk menyebut konflik atau sengketa yang terjadidilingkungan masyarakat desa. Sekalipun demikian tampaknya oleh pembuat undang-undang yang dimaksud dengan perselisihan itu tidak berbeda dengankonflik atau sengketa.Istilah konflik ini secara etimologis berasal dari bahasa Latin "con" yang berarti bersama, dan "fligere" yang berarti benturan atau tabrakan. Secara sosiologis, konflik diartikan sebagai suatu proses sosial antara dua orang atau lebih (bisa juga kelompok) dimana salah satu pihak berusaha menyingkirkan pihak lain dengan menghancurkannya atau

7 Johny Ibrahim, Teori dan Metodologi Penelitian Hukum Normatif, Malang: Bayumedia Publising, 2011, h. 46. 
membuatnya tidak berdaya.

Dengan demikian konflik dalam kehidupan sosial berarti terjadinya benturan kepentingan, pendapat, harapan yang harus diwujudkan dan sebagainya yang paling tidak melibatkan dua pihak atau lebih, dimana tiap-tiap pihak dapat berupa perorangan, keluarga, kelompok kekerabatan, satu komunitas, maupun satu organisasi sosial pendukung ideologi tertentu, satu organisasi politik, suku bangsa maupun satu pemeluk agama tertentu.

Peran seorang kepala desa menjadi sangat penting dalam penyelesaian perselisihan di masyarakat desa. Secara historis pada masa Hindia Belanda telah dikenal adanya peradilan desa. Melalui Stb. 1935, tahun 1935, Nomor 102 disisipkan Pasal 3 a ke dalam Rechterlijke Organisatie (RO) yang secara singkat menyebutkan tetap mengakui kewenangan hakim-hakim dari masyarakat hukum kecil-kecil (desa) untuk memeriksa perkara-perkara adat yang menjadi kewenangannya, untuk mengadili secara adat tanpa menjatuhkan hukuman.Kewenangan hakim-hakim ini tidak mengurangi kewenangan para pihak untuk setiap saat menyerahkan perkaranya kepada putusan hakim. Dengan disisipkannya pasal ini, kemudian diakui kedudukan peradilan desa. Dalam kenyataannya, selama pemerintahan kolonial Belanda dikenal dua bentuk peradilan bagi orang pribumi, yaitu peradilan adat dan peradilan desa.

Sejalan dengan ketentuan dalam Undang-Undang Nomor 6 Tahun 2014 tentang Desa yang menegaskan fungsi kepala desa sebagai penyelesai perselisihan. Pasal 26 (1) menyebutkan:

“Kepala Desa bertugas menyelenggarakan Pemerintahan Desa, melaksanakan

Pembangunan Desa, pembinaan kemasyarakatan Desa, dan pemberdayaan masyarakat Desa".

Selanjutnya Pasal 26 (4) huruf k. menyatakan dalam melaksanakan tugas sebagaimana dimaksud pada ayat (1), Kepala Desa berkewajiban: menyelesaikan perselisihan masyarakat di Desa. Dalam rangka menekankan fungsi kepala desa sebagai penyelesai perselisihan, Pasal 28 mengancam melalui sanksi, sebagaimana ditegaskan :

“Kepala Desa yang tidak melaksanakan kewajiban sebagaimana dimaksud dalam

Pasal 26 ayat (4) dan Pasal 27 dikenai sanksi administratif berupa teguran lisan dan/atau teguran tertulis".

Fungsi kepala desa sebagai penyelesai perselisihan sangat strategis dalam mendukung bekerjanya peradilan negara di Indonesia, apalagi ipso facto negara ini tengah mengalami perubahan dan pergeseran dari gemeinschaft (paguyuban) ke gesselschaft (patembayan). Dalam rangka memperkuat nilai-nilai paguyuban maka fungsi kepala desa sebagai penyelesai perselisihan berbasis kearifan lokal yang telah dipertegas oleh Undang-Undang Nomor 6 Tahun 2014 tentang Desa harus didayagunakan semaksimal mungkin sebagai ihktiar untuk memperluas akses keadilan bagi warga masyarakat.

Kepala desa yang berperan sebagai ujung tombak pertama dalam pelaksanaan pemerintahan harus mewujudkan semua program yang menjadi amanat negara. Untuk itu diperlukan kesiapan dan kemampuan guna meningkatkan kelancaran dalam penyelenggaraan pemerintahan, serta mendukung pelaksanaan pembangunan 
dan pelayanan kepada masyarakat sesuai dengan perkembangan dan tuntutan reformasi. Mengacu pada hal tersebut perlu adanya upaya guna meningkatkan kemampuan kepala desa di bidang pendamai perselisihan masyarakat desa, diantaranya :

1. Peka terhadap Persoalan Masyarakat

2. Kemampuan Menangkap Obyek masalah Sengketa

3. Kepiawaian mengakomodir pendapat para pihak yang bersengketa

4. Ketepatan Memutus Suatu Perkara Sengketa

5. Pemahaman Keilmuan Bidang Penyelesaian Sengketa Baik Litigasi Maupun Non Litigasi

6. Kedewasaan sebagai Fasilitator atau Penengah Sengketa

7. Mampu membuat keputusan secara muyawarah untuk mufakat sehingga dapat diterima semua pihak

8. Mampu mendokumentasikan hasil musywarah dalam bentuk risalah perundingan sebagai dasar pengambilan keputusan

Dengan demikian, peranan kepala desa bukan hanya melingkupi persoalan pemerintahan saja. Melainkan juga mempunyai tugas, kewajiban dan wewenang untuk menyelesaikan perselisihan atau mendamaikan kedua belah pihak dari warga yang bersengketa dengan dibantu oleh perangkat desa lain. Hemat penulis, kepala desa sebagai pendamai perselisihan dalam bentuk perdamaian desa ini merupakan cara penyelesaian sengketa di luar pengadilan. Yang mana dapat membantu para pihak untuk mempercepat penyelesaian sengketanya serta menghindari menumpuknya perkara melalui jalur litigasi (pengadilan). ${ }^{35}$ Dengan adanya pelibatan semua pihak dapat menunjukkan polarisasi tenggang rasa (toleransi) yang tinggi diantara pihak dan suasana rukun sebagai integrasi masyarakat dapat dipertahankan. Hal ini juga tidak lain diambil dari toleransi dan kebersamaan dalam hukum adat suatu daerah. Dimana hukum adat di berbagai daerah Indonesia memiliki kriteria seperti tersebut di atas. Sehingga, dari semua proses diatas, nantinya media peradilan desa ini dapat berperan dalam mengurangi banyaknya berkas perkara yang diselesaikan di pengadilan.

\section{Kendala dan Solusi dalam Penyelesaian Perselisihan Masyarakat Desa}

Kelebihan yang dimilki fungsi kepala desa sebagai penyelesai perselisihan yang demikian itu akan sangat signifikan dalam mengurangi arus masuknya perkara ke peradilan negara yang sekarang sudah overload. Banyak sengketa perdata dan perkara pidana adat atau delik aduan akan lebih efektif dan efisien diselesaikan oleh peradilan informal (peradilan adat) yang diharapkan dapat memberikan rasa adil. Temuan di lapangan bahwa berdasarkan pengamatan dan informasi diperoleh informasi bahwa kepala desa sering menjadi mediator perselisihan warganya dalam masalah perkelahian warga, perceraian dan sengketa warisan.

${ }^{35}$ Tjok Istri Putra Astiti, 1997, Pemberdayaan Hakim Perdamaian Desa dalam Penyelesaian Kasus Adat di Luar Pengadilan. Pidato pengukuhan dalam bidang Ilmu Hukum Adat, Fakultas Hukum Universitas Udayana. Majalah Musyawarah Nomor 1 Tahun I. Jakarta: Indoesia Center for Environmental Law, h. 6. dalam buku Rachmadi Usman, Op.Cit. 
Artinya sengketa yang terjadi masyakarakat sebenarnya sangat potensial meluas, sehingga dibutuhkan kesadaran masyarakat desa dan kepala desa untuk menyelesaiakan masalah secara damai melalui pemimpin desa dalam hal ini kepala desa sebagai authoritative mediator. Adapun untuk mekanisme mediasi yang dilakukan tiap-tiap kepala desa dalam mendamaikan perselisihan warga desa tergantung dari gaya kepemimpinan masing-masing desa. Namun, dapat dicatat pada dasarnya semua kepala desa lebih mengedepankan win-win solution. Mekanisme mediasi kepala desa dengan mengundang pihak-pihak yang berselisih ke Balai Desa untuk diadakan musyawarah.Melakukan Pendekatan persuasif dan dipertemukan kedua belah pihak untuk mencari solusi terbaik supaya tidak timbul masalah lagi, menghasilkan keputusan yang baik untuk semuanya.Teknisnya dengan mengumpulkan keterangan dari masing-masing pihak kemudian menyampaikan berbagai alternatif penyelesaian yang dipilih oleh masingmasing pihak sehingga maslah yang dihadapi dapat diselesaikan secara tuntas tanpa ada yang merasa menang dan kalah dengan pendekatan win-winsolution.

Berdasarkan hal tersebut, hemat penulis bahwa sebuah kontribusi positif khususnya bagi kepala-kepala desa atau pemerintah desa guna membantu kelancaran jalannya penyelesaian perselisihan. Kepala Desa kedepan diharapkan mampu menyelesaikan persoalan di bidang pendamai perselisihan masyarakat desa guna mencapai tujuan hakikat otonomi daerah yang diharapkan untuk menumbuhkan ketertiban masyarakat. Implementasi Tugas dan Fungsi Kepala Ngeni, Kecamatan Wonotirto, Kabupaten Blitar masih di dapatkan beberapa kendala yang menghambat proses jalannya penyelesaian perselisihan dengan baik, kendala tersebut antara lain:

1. Sumber daya manusia yang kurang berkualitas sangat mempengaruhi penyelesaian perselisihan

2. Adanya masyarakat yang pro dan kontra dengan putusan kepala desa

3. Kepala desa kurang mendengar aspirasi msyarakat dan kurangnya komunikasi dengan warga desa

4. Kesadaran masyarakat yang minim akan peraturan desa

5. Minimnya dana guna menopang program kerja

6. Rendahnya tingkat kesadaran masyarakat dalam menyelesaikan permasalahan secara bersama

7. Minimnya kemampuan perangkat dibawahnya.

9. Para pihak saling mengutamakan kepentingan pribadi (ego)

10.Kurangnya ilmu pengetahuan kepala desa di dalam setiap kebijakannya, serta tidak jelasnya pembagian kerja

11. Minimnya pelatihan paralegal, rendahnya ruang diskursus publik. Rendahnya kegemaran membaca

12. Kecenderungan untuk memihak para pihak yang terikat hubungan emosional serta "gila" hormat

13. Tarik ulur kepentingan hingga deadlock.

Perselisihan dan konflik akan selalu muncul dalam kehidupan bermasyarakat. Berbagai faktor yang menjadi penyebab terjadinya konflik sosial adalah : 
1. Perbedaan Pendirian. Perbedaan pendirian tak jarang menjadi penyebab timbulnya konflik sosial. Dalam suatu masyarakat desa, seringkali terjadi perbedaan pendapat atau perbedaan cara pandang akan sesuatu hal misalnya sikap politik. Tak jarang, perbedaan sikap politik menjadi benih timbulnya konflik sosial dalam masyarakat.

2. Perbedaan keyakinan. Perbedaan keyakinan seringkali memicu konflik sosial dalam masyarakat. Kini masyarakat semakin permisif terhadap penggunaan cara-cara kekerasan guna menegakkan prinsip-prinsip agama yang dianut. Hal ini tidak hanya terjadi antar pemeluk agama, namun sesama pemeluk agama juga tidak jarang mengalami hal ini.

3. Perbedaan kebudayaan. Kebudayaan yang berbeda antara kebudayaan setempat dan kebudayaan dari luar wilayahnya juga memberikan kontribusi sebagai salah satu faktor penyebab timbulnya konflik sosial.

4. Perbedaan kepentingan - Setiap orang memiliki kepentingan yang berbeda satu sama lain. Perbedaan ini dapat menimbulkan konflik dalam masyarakat. Misalnya saja demontrasi sopir taksi konvensional yang terjadi beberapa waktu yang lalu yang berakhir dengan bentrokan. Mereka menolak keberadaan taksi berbasis online yang dianggap mengambil penghasilan mereka.

5. Perubahan sosial - Konflik sosial dapat memicu adanya perubahan sosial, begitu juga sebaliknya.

Penyelesaian atau pemecahan masalah adalah bagian dari proses berpikir. Sering dianggap merupakan proses paling kompleks di antara semua fungsi kecerdasan, pemecahan masalah telah didefinisikan sebagai proses kognitif tingkat tinggi yang memerlukan modulasi dan kontrol lebih dari keterampilan-keterampilan rutin atau dasar. Proses ini terjadi jika suatu organisme atau sistem kecerdasan buatan tidak mengetahui bagaimana untuk bergerak dari suatu kondisi awal menuju kondisi yang dituju. Adapun Solusi dalam mengatasi kendala dalam pelaksanaan tugas dan fungsi kepala desa Ngeni dalam menyelesaikan masalah antara lain :

1. Harus ada kesadaran dari masyarakat desa agar ikut mengawasi jalannya roda pemerintahan desa

2. Kepala desa harus lebih mendengar keluhan dari masyarakat

3. Pembinaan perekonomian desa harus lebih di tingkatkan

4. Meningkatkan kesadaran dalam mematuhi peraturan desa

5. Mengajak kaum muda diharapkan mampu memberikan solusi dalam membina dan menyelsaiakan permasalahan desa

6. Meningkatkan komunikasi yang baik antara kepala desa dengan lembaga pemerintahan desa lainnya agar terjalin kerjasama yang baik.

7. Penyusunan anggaran desa secara proporsional dan transparan sebagai salah satu cara untuk meminimalisir persoalan sosial

8. Melakukan komunikasi dua arah dengan masyarakat.

8. Mengefektifkan fungsi tokoh masyarakat maupun unsur struktural di wilayah desa Ngeni seperti kepala Dusun, RW dsbnya untuk menjaring data guna memdapatkan fakta hukum yang bisa dipertanggungjawabkan. 
9. Kepala desa terlibat aktif selaku mediator dengan memberikan penjelasan, saran dan pentingnya kebersamaan (toleransi).

10. Masyarakat lebih selektif dalam memilih kepala desa.

11. Menjalin kerjasama dengan pemerintah daerah setempat untuk mengadakan pelatihan peningkatan SDM periodik secara gratis.

12. Pelibatan tokoh masyarakat dalam mencari solusi bersama.

13. Disarankan menempuh jalur litigasi.

14. Secara aktif memanfaatkan media yang ada dalam bentuk pencatatan atas informasi yang terkait dengan pentingnya mendokumentasi hasil musyawarah sebagai peraturan bagi yang berselisih.

Melalui peran dan fungsi Kepala Desa sebagai penyelesai perselisihan dalam hal ini terjadi perselisihan dalam masyarakat sebagai upaya memperkuat nilai-nilai paguyuban tentram dan damai yang telah ditegaskan oleh Undang-Undang Desa, harus didayagunakan semaksimal mungkin sebagai ikhtiar untuk memperluas akses keadilan bagi warga masyarakat. Guna membekali Kepala Desa dengan kemampuan layaknya mediator penyelesaian sengketa profesional, diselenggarakan pendidikan dan pelatihan Kepala Desa, dengan keuntungan yang diperoleh para pihak yang berselisih melalui penyelesaian oleh Kepala Desa adalah para pihak yang berselisih tidak terperangkap dengan formalitas acara sebagaimana dalam proses litigasi. Para pihak dapat menentukan cara-cara yang lebih sederhana dibandingkan dengan proses beracara formal di Pengadilan. Jika penyelesaian sengketa melalui litigasi dapat diselesaikan bertahun-tahun, jika kasus terus naik banding, kasasi, sedang pelihan penyelesaian sengketa melalui mediasi lebih singkat, karena tidak terdapat banding atau bentuk lainnya.Sehingga dalam setiap penyelesaian sengketa masyarakat desa seyogyanya kepala desa ikut lebih memperhatikan hal-hal yang disebutkan diatas. Pada prinsipnya dalam setiap mekanisme ada pihak-pihak yang harus berpera aktif yakni kepala desa, masyarakat, tokoh desa (pemuka adat atau agama) dan para pihak yang bersengketa.

\section{PENUTUP}

Peran dan Kewenangan untuk kepala desa di bidang pendamai perselisihan masyarakat desa terdapat dalam Pasal 26 (4) huruf K Undang-Undang Nomor 6 Tahun 2014 tentang Desa yang menegaskan fungsi kepala desa dimana Kepala desa berkewajiban menyelesaikan perselisihan masyarakat di Desa. Fungsi tersebut memberikan bahwa Kepala desa mempunyai peran yakni Kepala Desa harus peka terhadap persoalan masyarakat, kemampuan menangkap obyek masalah, kepiawaian mengakomodir pendapat para pihak, ketepatan memutus perkara, pemahaman keilmuan di bidang penyelesaian sengketa baik litigasi maupun non litigasi, kedewasaan sebagai fasilitator atau penengah sengketa serta mampu membuat keputusan secara muyawarah untuk mufakat sehingga dapat diterima semua pihak.

Adapun kendala yang menghambat proses jalannya penyelesaian perselisihan dengan baik, antara lain:Sumber daya manusia yang kurang berkualitas sangat mempengaruhi penyelesaian perselisihan, Adanya masyarakat yang pro dan kontra 
dengan putusan kepala desa, Kepala desa kurang mendengar aspirasi msyarakat dan kurangnya komunikasi dengan warga desa, Kesadaran masyarakat yang minim akan peraturan desa, Minimnya dana guna menopang program kerja, Rendahnya tingkat kesadaran masyarakat dalam menyelesaikan permasalahan secara bersama, Minimnya kemampuan perangkat dibawahnya, Para pihak saling mengutamakan kepentingan pribadi (ego), Kurangnya ilmu pengetahuan kepala desa di dalam setiap kebijakannya, serta tidak jelasnya pembagian kerja, Minimnya pelatihan paralegal, rendahnya ruang diskursus publik. Rendahnya kegemaran membaca, Kecenderungan untuk memihak para pihak yang terikat hubungan emosional serta "gila" hormat, Tarik ulur kepentingan hingga deadlock. Adapun solusi dalam mengatasi kendala dalam pelaksanaan tugas dan fungsi kepala desa Ngeni dalam menyelesaikan masalah antara lain : Harus ada kesadara dari masyarakat desa agar ikut mengawasi jalannya roda pemerintahan desa,. Kepala desa harus lebih mendengar keluhan dari masyarakat, Pembinaan perekonomian desa harus lebih di tingkatkan, Meningkatkan kesadaran dalam mematuhi peraturan desa, Mengajak kaum muda diharapkan mampu memberikan solusi dalam membina dan menyelsaiakan permasalahan desa, Meningkatkan komunikasi yang baik antara kepala desa dengan lembaga pemerintahan desa lainnya agar terjalin kerjasama yang baik, Penyusunan anggaran desa secara proporsional dan transparan sebagai salah satu cara untuk meminimalisir persoalan social, Melakukan komunikasi dua arah dengan masyarakat, Mengefektifkan fungsi tokoh masyarakat maupun unsur struktural di wilayah desa Ngeni seperti kepala Dusun, RW dsbnya untuk menjaring data guna memdapatkan fakta hukum yang bisa dipertanggungjawabkan, Kepala desa terlibat aktif selaku mediator dengan memberikan penjelasan, saran dan pentingnya kebersamaan (toleransi), Masyarakat lebih selektif dalam memilih kepala desa, Menjalin kerjasama dengan pemerintah daerah setempat untuk mengadakan pelatihan peningkatan SDM periodik secara gratis, Pelibatan tokoh masyarakat dalam mencari solusi bersama, Disarankan menempuh jalur litigasi, Secara aktif memanfaatkan media yang ada dalam bentuk pencatatan atas informasi yang terkait dengan pentingnya mendokumentasi hasil musyawarah sebagai peraturan bagi yang berselisih.

\section{DAFTAR PUSTAKA}

\section{Buku}

Ibrahim, Johny, Teori dan Metodologi Penelitian Hukum Normatif, Malang: Bayumedia Publising, 2011

James, P. Spradley and David W. McCurdy, Conformity and Conflict,Reading in Cultural Antropogy, Little Brown and Company, 1987

Ridwan HR, Hukum Administrasi Negara, Yogyakarta: UII Press, 2002

Sulistiyono, Adi. Mengembanngkan Paradigma Non-Litigasi di Indonesia. Sebelas Maret University Press: Surakarta, 2006.

Surasih, Maria Eni, Pemerintahan Desa dan Implementasinya, Jakarta: Erlangga, 2006. 


\section{Artikel dan Jurnal}

I Putu Gelgel. 2011. Peradilan Adat (Agama) Sebagai Resolusi Konflik.Bali Pos, Senin, 06 Oktober 2011.

Tjok Istri Putra Astiti. Pemberdayaan Hakim Perdamaian Desa dalam Penyelesaian Kasus Adat di Luar Pengadilan. Pidato pengukuhan dalam bidang Ilmu Hukum Adat, Fakultas Hukum Universitas Udayana. Majalah Musyawarah Nomor 1 Tahun I. Jakarta: Indoesia Center for Environmental Law. 1997.

\section{Perundang-Undangan}

Undang-undang Nomor 6 tahun 2014 tentang desa

Peraturan Pemerintah Republik Indonesia Nomor 47 Tahun 2015 Tentang Perubahan Atas Peraturan Pemerintah Nomor 43 Tahun 2014 Tentang Peraturan Pelaksanaan Undang-Undang Nomor 6 Tahun 2014 Tentang Desa

\section{Internet :}

http://www.negarahukum.com/hukum/pengertian-kewenangan.html http://enter-comp.blogspot.com/2011/11/sejarah-singkat-desa-ngeni-masalampau.html

Agung Septian Wijanarko, Peran Badan Usaha Milik Desa Dalam Pemberdayaan Masyarakat, http://eprints.upnjatim.ac.id/1/file 1.pdf 